University of Nebraska - Lincoln

DigitalCommons@University of Nebraska - Lincoln

Agronomy \& Horticulture - Faculty Publications

Agronomy and Horticulture Department

2015

\title{
Model and Sensor-Based Recommendation Approaches for In- Season Nitrogen Management in Corn
}

L. J. Thompson

University of Nebraska-Lincoln, laura.thompson@unl.edu

R. B. Ferguson

University of Nebraska-Lincoln, rferguson1@unl.edu

N. Kitchen

USDA

D. W. Frazen

North Dakota State University--Fargo

M. Mamo

University of Nebraska-Lincoln, mmamo3@unl.edu

See next page for additional authors

Follow this and additional works at: https://digitalcommons.unl.edu/agronomyfacpub

Part of the Agricultural Science Commons, Agriculture Commons, Agronomy and Crop Sciences Commons, Botany Commons, Horticulture Commons, Other Plant Sciences Commons, and the Plant Biology Commons

Thompson, L. J.; Ferguson, R. B.; Kitchen, N.; Frazen, D. W.; Mamo, M.; Yang, H.; and Schepers, J. S., "Model and Sensor-Based Recommendation Approaches for In-Season Nitrogen Management in Corn" (2015). Agronomy \& Horticulture -- Faculty Publications. 982.

https://digitalcommons.unl.edu/agronomyfacpub/982

This Article is brought to you for free and open access by the Agronomy and Horticulture Department at DigitalCommons@University of Nebraska - Lincoln. It has been accepted for inclusion in Agronomy \& Horticulture -Faculty Publications by an authorized administrator of DigitalCommons@University of Nebraska - Lincoln. 


\section{Authors}

L. J. Thompson, R. B. Ferguson, N. Kitchen, D. W. Frazen, M. Mamo, H. Yang, and J. S. Schepers 


\title{
Model and Sensor-Based Recommendation Approaches for In-Season Nitrogen Management in Corn
}

\author{
L. J. Thompson,* R. B. Ferguson, N. Kitchen, D. W. Frazen, M. Mamo, H. Yang, and J. S. Schepers
}

\begin{abstract}
Nitrogen management for corn (Zea mays L.) maybe improved by applying a portion of $\mathrm{N}$ in-season. This investigation was conducted to evaluate crop modeling (Maize-N) and active crop canopy sensing approaches for recommending in-season $\mathrm{N}$ fertilizer rates. These approaches were evaluated during 2012-2013 on 11 field sites, in Missouri, Nebraska, and North Dakota. Nitrogen management also included a no-N treatment (check) and a non-limiting $\mathrm{N}$ reference (all at planting). Nitrogen management treatments were assessed for two hybrids and at low and high seeding rates, arranged in a randomized complete block design. In 9 of 11 site-years, the sensor-based approach recommended lower in-season $\mathrm{N}$ rates than the model (collectively 59\% less N), resulting in trends of higher partial factor productivity of nitrogen $\left(\mathrm{PFP}_{\mathrm{N}}\right)$ and higher agronomic efficiency (AE) than the model. However, yield was better protected by the model-based approach. In some situations, canopy sensing excelled at optimizing the $\mathrm{N}$ rate for localized conditions. With abnormally warm and moist soil conditions for the 2012 Nebraska sites and presumed high levels of inorganic $\mathrm{N}$ from mineralization, $\mathrm{N}$ application was appropriately reduced, resulting in no yield decrease and $\mathrm{N}$ savings compared to the non-limiting $\mathrm{N}$ reference. Depending on the site, both recommendation approaches were successful; a combination of model and sensor information may optimize in-season decision support for $\mathrm{N}$ recommendation.
\end{abstract}

Published in Agron. J. 107:2020-2030 (2015)

doi:10.2134/agronj15.0116

Received 9 Mar. 2015

Accepted 13 June 2015

Copyright (c) 2015 by the American Society of Agronomy 5585 Guilford Road, Madison, WI 53711

All rights reserved This document is a U.S. government work and is not subject to copyright in the United States.

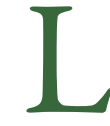
OW NITROGEN USE EFFICIENCY (NUE) has been attributed to several factors including poor synchrony between $\mathrm{N}$ fertilizer application and crop demand, unaccounted for spatial variability resulting in varying crop $\mathrm{N}$ needs, and temporal variance in crop $\mathrm{N}$ needs (Shanahan et al., 2008). It is estimated that $75 \%$ of $\mathrm{N}$ fertilizer is applied before planting (Cassman et al., 2002), resulting in high levels of inorganic $\mathrm{N}$, such as nitrate, in the soil before the stage of rapid crop uptake occurs. Because of this, improvements in NUE can be achieved by attaining greater synchrony between the crop $\mathrm{N}$ need and the $\mathrm{N}$ which is available to the plant from all sources throughout the growing season (Cassman et al., 2002). Applying a portion of the $\mathrm{N}$ fertilizer alongside the growing crop allows $\mathrm{N}$ availability to coincide more closely with the time of the crop $\mathrm{N}$ needs and is expected to increase NUE. Spatial variability of soil properties presents further challenges to $\mathrm{N}$ management. Nitrogen supplying capacity can vary throughout a field. Mamo et al. (2003), showed that $\mathrm{N}$ mineralization of soil organic matter (SOM) varied spatially within a field. Additionally, the $\mathrm{N}$ fertilizer need by the crop can vary spatially across a field, due to varying yield potential. Mineralization of $\mathrm{N}$ is also dependent on soil water and temperature, which vary with landscape position; therefore SOM content should not be used as a sole criterion when delineating $\mathrm{N}$ management zones (Schmidt et al., 2002). Managing $\mathrm{N}$ application based on spatial variability can reduce the overall $\mathrm{N}$ rate applied and increase profitability compared with a uniform $\mathrm{N}$ application (Mamo et al., 2003). Variable rate application of $\mathrm{N}$ decreases the risk of overfertilization or underfertilization, compared with uniform applications. In addition to the spatial variability component of $\mathrm{N}$ management, temporal variations in $\mathrm{N}$ response and $\mathrm{N}$ mineralization related to environmental factors have also been observed (Mamo et al., 2003; Scharf et al., 2006). Climate and management interactions can cause

L.J. Thompson, Univ. Nebraska-Lincoln, Southeast Reasearch and Extension Center, 1071 CR G, Ithaca NE 68033; R.B. Ferguson, M. Mamo, and H. Yang, Argonomy and Horticulture, Univ. of NebraskaLincoln, 377K Plant Science, Lincoln, NE 68583; N. Kitchen, USDA, 243 Ag. Eng. Building, Columbia, MO 65211; D.W. Frazen, Soil Science, North Dakota State Univ., Dep. 7680, Fargo, ND 58108; and J.S. Schepers (retired), USDA-ARS and Dep. of Agronomy and Horticulture, Univ. of Nebraska-Lincoln, Lincoln, NE 68583. *Corresponding author (laura.thompson@unl.edu).

Abbreviations: AE, agronomic efficiency; CI, chlorophyll index; EONR, economically optimum nitrogen rate; LAI, leaf area index; LOI, loss on irrigation; ME, mean error; NDRE, normalized difference red edge; NDVI, normalized difference vegetation index; NUE, nitrogen use efficiency; ONR, optimum nitrogen rate; $\mathrm{PFP}_{\mathrm{N}}$, partial factor productivity of nitrogen; SI, sufficiency index; SOC, soil organic carbon; SOM, soil organic matter. 
considerable year-to-year variation in both crop $\mathrm{N}$ requirement and yield (Cassman et al., 2002). Together, spatial and temporal variation creates uncertainty as to the optimal $\mathrm{N}$ fertilizer quantity for any given year (Roberts et al., 2010). Determining the amount and timing of $\mathrm{N}$ needed by the crop over a spatially diverse field is critical for improving NUE.

Active crop canopy sensors are available to assess the $\mathrm{N}$ status of the crop, allowing growers to make management decisions that are reactive to actual growing season conditions, thereby improving NUE (Cassman et al., 2002). Sensors can be an effective indicator of in-season crop need as they serve to integrate the conditions and stresses that have already occurred during the early growing season. Crop canopy sensors are designed to detect specific wavelengths of light reflected from crop canopies. These wavelengths are combined to form vegetation indices that are correlated with specific crop conditions of interest. The normalized difference vegetation index (NDVI) was developed to quantify living biomass and as such is the most widely recognized vegetation index (Hatfield et al., 2008). Other indices such as the chlorophyll index (CI) and normalized difference red-edge (NDRE) index are considered more useful in terms of characterizing crop $\mathrm{N}$ status because they are not subject to red waveband saturation as with NDVI (Gitelson and Merzlyak, 1995). Crop vegetation indices are typically used to generate field maps that illustrate spatial variability in crop vigor. Shanahan et al. (2001) showed that several of these indices were well correlated with corn yields, especially once crop growth was adequate to minimize soil reflectance.

Another application of vegetation indices generated from crop canopy sensor data is the transformation into algorithms for making fertilizer $\mathrm{N}$ recommendations. Several sensor-based algorithms have been developed in recent years. Algorithms that are based on remote or proximal sensing data use the crop as a biological indicator of soil $\mathrm{N}$ supply that includes residual soil $\mathrm{N}$ and mineralized $\mathrm{N}$ within the root zone. As such, excess soil $\mathrm{N}$ renders the crop non-responsive in terms of biomass and leaf chlorophyll content, however, modest applications of pre-plant $\mathrm{N}$ can be used to render the crop sensitive to $\mathrm{N}$ status at the time when in-season $\mathrm{N}$ application is planned (Miao et al., 2009; Solari et al., 2008). Additionally, these algorithms are generally linked to the features of a given sensor. For example, scientists at Oklahoma State University developed the GreenSeeker (N-Tech Industries, Ukiah, CA) active sensor that utilizes modulated red and near infrared (NIR) wavebands to quantify the amount of bare soil in wheat fields early in the growing season (Raun et al., 2002). Their algorithm was based on the relationship between sensor data collected early in the growing season and the yield attained across years and locations. Current-year sensor-generated vegetation index values were used in this general relationship to predict yield potential and expected nutrient removal rates to generate an $\mathrm{N}$ recommendation. This sensor and algorithm approach has been extended to other crops, including corn. Because this sensor uses the red waveband reflectance, sensitivity to true differences in crop vigor (chlorophyll content and biomass) can be negated by the insensitivity of red waveband reflectance when the leaf area index (LAI) exceeds about 2.0 or canopy closure (Gitelson et al., 1996).
Sensors with capability to use the red-edge waveband reflectance retain good sensitivity over a wider range of applications. Holland Scientific (Lincoln, NE) developed a series of active crop canopy sensors to avoid the red waveband saturation limitation by including red-edge reflectance. Concurrently, they developed a general algorithm that is based on the biological response of crops to soil $\mathrm{N}$ supply (Holland and Schepers, 2010). This algorithm requires the user to estimate the optimum nitrogen rate (ONR) which takes into account other $\mathrm{N}$ sources available to the crop (previously applied N, N credits from a previous crop, manure application, and irrigation water N). Crop N uptake at a given growth stage is estimated based on phenologic information.

Crop simulation modeling has also been identified as an approach for precision $\mathrm{N}$ management and has potential to synchronize fertilizer $\mathrm{N}$ application with crop $\mathrm{N}$ demand, thereby potentially increasing NUE (Cassman et al., 2002; Ferguson et al., 2002; Kersebaum, 1995). Although many existing crop simulation models, such as CERES-Maize in DSSAT (Jones et al., 2003), APSIM (Keating et al., 2003), WOFOST (Supit and Van der Goot, 2003), and CropSys (Stöckle et al., 2003) have functions to account for crop biomass accumulation and yield growth in response to $\mathrm{N}$ availability in a corn crop, they were not designed to support pre-plant or in-season decisions about fertilizer $\mathrm{N}$ management. Specific simulation models for pre-plant and in-season $\mathrm{N}$ management for crops like corn also have been developed. Three such examples include the QUEFTS model (Janssen et al., 1990; Smaling and Janssen, 1993), the Adapt-N model (Melkonian et al., 2008), and the Maize-N model (Setiyono et al., 2011). The QUEFTS model was developed for corn based on data from eastern Africa and can provide recommendations for nutrients including $\mathrm{N}, \mathrm{P}$, and $\mathrm{K}$. The model primarily requires information about soil nutrients and SOM, soil $\mathrm{pH}$, and pricing information for the corn crop and fertilizers to predict optimum rates for N, P, K, and expected corn yield. The Adapt-N model was developed using the $\mathrm{N}$ management scheme from Melkonian et al. (2005, 2007), and corn growth and N uptake from Sinclair and Muchow (1995). It uses gridded weather data ( 5 by $5 \mathrm{~km}$ ) and has functions to account for $\mathrm{N}$ losses through leaching. The Maize- $\mathrm{N}$ model adopts the functions from the HybridMaize model (Yang et al., 2006) for maize yield prediction, and Yang and Janssen (2000) for SOM mineralization and generic response of corn yield to $\mathrm{N}$ uptake. This model has been validated in experiments in central Nebraska, eastern South Dakota, and western Nebraska, including both irrigated and rainfed systems (Setiyono et al., 2011). The economic optimum nitrogen rate (EONR) simulated by Maize-N and the EONR generated with more empirical university $\mathrm{N}$ recommendation approaches were compared to actual observed EONR; EONR simulated by Maize- $\mathrm{N}$ was found to have greater accuracy than the university $\mathrm{N}$ recommendation approaches as shown by lower RMSE and mean error (ME).

The objective of this study was to evaluate canopy reflectance sensing and crop modeling approaches for determining in-season maize $\mathrm{N}$ rates over a multi-state region. Additionally, the study investigated the effects of hybrid and population on these two $\mathrm{N}$ recommendation strategies. 
Table I. Characteristics of research sites and cropping information including site yield potential classification, predominant soil subgroup and texture, organic matter, extractable $\mathrm{P}$ and $\mathrm{K}$, soil $\mathrm{pH}$, residual $\mathrm{NO}_{3}-\mathrm{N}$ and previous crop in Nebraska (NE), Missouri (MO), and North Dakota (ND). Samples were taken before seeding.

\begin{tabular}{|c|c|c|c|c|c|c|c|c|c|}
\hline Site ID & $\begin{array}{l}\text { Site yield } \\
\text { potential }\end{array}$ & $\begin{array}{l}\text { Predominant } \\
\text { soil subgroup }\end{array}$ & $\begin{array}{c}\text { Soil } \\
\text { texturet }\end{array}$ & $\begin{array}{c}\text { Soil } \\
\text { organic } \\
\text { matter }\end{array}$ & $\begin{array}{c}\text { Extractable } \\
\text { P }\end{array}$ & $\begin{array}{c}\text { Extractable } \\
\mathrm{K}\end{array}$ & $\mathrm{pH}$ & $\mathrm{NO}_{3}-\mathrm{N}$ & $\begin{array}{c}\text { Previous } \\
\text { crop }\end{array}$ \\
\hline & & & & $\mathrm{g} \mathrm{kg}^{-1}$ & $-\mathrm{mg}$ & $\mathrm{kg}^{-1}$ & & $\begin{array}{l}\mathrm{g} \mathrm{kg}^{-1} \text { for top } \\
0.6096 \mathrm{~m}\end{array}$ & \\
\hline MOLTI2 & moderate & Vertic Epiaqualfs & SiL & 26 & II BIP & 60 & 5.7 & 5.3 & soybean \\
\hline $\mathrm{NECCI} 2$ & high & Pachic Udertic Argiustolls & SiL & 39 & $27 \mathrm{M} 3 \mathrm{P} \oint$ & 482 & 6.4 & 18.3 & corn \\
\hline NEMCI 2 & moderate & Cumulic Haplustolls & SL & 17 & 4I M3P & 326 & 6.7 & 9.3 & corn \\
\hline NDDNI 2 & high & Typic Epiaquerts & $\mathrm{SiCL}$ & 53 & 32 OPI & 600 & 7.6 & 6.3 & corn \\
\hline NDVCI 2 & moderate & Calcic Hapludolls & $L$ & 36 & $10 \mathrm{OP}$ & 300 & 6.3 & 10.1 & wheat \\
\hline MOTRI3 & high & Fluventic Hapludolls & SiL & 19 & $29 \mathrm{BIP}$ & 150 & 6.8 & $2.8 \#$ & soybean \\
\hline MOBAI3 & moderate & Vertic Epiaqualfs & $\mathrm{SiC}$ & 19 & II BIP & 76 & 6.8 & $2.8 \#$ & soybean \\
\hline NECCI 3 & high & Udic Argiustolls & SiL & 28 & $23 \mathrm{M} 3 \mathrm{P}$ & 428 & 6.4 & 3.8 & soybean \\
\hline NEMCI 3 & moderate & Oxyaquic Haplustolls & SL & 21 & $29 \mathrm{M} 3 \mathrm{P}$ & 212 & 7.5 & 8.9 & corn \\
\hline NDARI3 & high & Typic Epiaquerts & $\mathrm{SiCL}$ & 34 & $5 \mathrm{OP}$ & 120 & 8.0 & 9.2 & soybean \\
\hline NDVCI3 & moderate & Calcic and Pachic Hapludolls & SL & 36 & 19 OP & 160 & 6.4 & 15.7 & wheat \\
\hline
\end{tabular}

† SiL = silt loam, $\mathrm{SL}=$ sandy loam, $\mathrm{SiCL}=$ silty clay loam, $\mathrm{L}=$ loam, $\mathrm{SiC}=$ silty clay.

$\ddagger \mathrm{BIP}=$ Bray I-P Extract.

$\S M 3 P=$ Mehlich-3 Extract.

II OP = Olsen Extract.

\# Estimated value.

Table 2. Monthly precipitation totals and average temperature for each site in Nebraska (NE), Missouri (MO), and North Dakota (ND). Irrigation values are included with monthly precipitation totals for sites indicated as irrigated.

\begin{tabular}{|c|c|c|c|c|c|c|c|}
\hline Site ID & April & May & June & July & Aug. & Sept. & Total \\
\hline & \multicolumn{7}{|c|}{ Precipitation and irrigation } \\
\hline MOLTI2† & - & $1.3(5 / 13) \ddagger$ & 30.7 & 95.5 & 48.3 & $38.9(9 / 19) \S$ & 214.6 \\
\hline $\mathrm{NECCI} 2 \dagger$ & $49.5(4 / I) \ddagger$ & 117.0 & 73.7 & 62.8 & 47.0 & I $3.7(9 / 30) \S$ & 363.7 \\
\hline $\mathrm{NEMCI} 2 \dagger$ & $2.8(4 / 1) \ddagger$ & 122.7 & 44.5 & 7.9 & $31.2(8 / 28) \S$ & - & 449.8 \\
\hline NDDNI2 & - & $3.3(5 / 25) \ddagger$ & 79.0 & 41.7 & 25.1 & $8.4(9 / 22) \S$ & 157.48 \\
\hline NDVCI 2 & - & - & $99.3(6 / 1) \dagger$ & 21.3 & 37.1 & II.9 (9/22)§ & 169.7 \\
\hline MOTRI3 & - & I55.7 (5/I)‡ & 159.0 & 66.3 & 94.5 & $80.3(9 / 30) \S$ & 555.7 \\
\hline MOBAI 3 & - & $265.2(5 / 1) \ddagger$ & 47.0 & $4 I . I$ & 44.7 & $42.9(9 / 30) \S$ & 441.0 \\
\hline NECCI3† & $57.9(4 / 1) \ddagger$ & 198.4 & 18.3 & 274.6 & 199.9 & $35.8(9 / 30) \S$ & 784.9 \\
\hline NEMCI3† & - & $103.4(5 / I) \ddagger$ & 50.5 & 116.6 & 88.6 & $87.9(9 / 30) \S$ & 447.0 \\
\hline NDARI3 & - & $49.0(5 / 28) \ddagger$ & 286.5 & 26.9 & 49.8 & $94.7(9 / 23) \S$ & 507.0 \\
\hline \multirow[t]{2}{*}{ NDVCI3 } & - & $59.7(5 / 20) \ddagger$ & 107.2 & 34.5 & 20.8 & $73.7(9 / 30) \S$ & 295.9 \\
\hline & \multicolumn{7}{|c|}{ Average temperature } \\
\hline MOLTI2 & & $21.4(5 / 13) \ddagger$ & 24.6 & 29.1 & 25.4 & $20.4(9 / 19) \S$ & \\
\hline $\mathrm{NECC} 12$ & $12.7(4 / 1) \ddagger$ & 18.7 & 23.1 & 25.9 & 21.9 & $17.8(9 / 30) \S$ & \\
\hline NEMCI 2 & $12.6(4 / 1) \ddagger$ & 18.4 & 22.9 & 26.2 & $22.1(8 / 28) \S$ & - & \\
\hline NDDNI 2 & - & $19.0(5 / 25) \ddagger$ & 7.5 & 7.5 & 20.1 & I $4.8(9 / 22) \S$ & \\
\hline NDVCI 2 & - & - & $20.2(6 / 1)$ & 24.1 & 20.1 & $14.8(9 / 22) \S$ & \\
\hline MOTRI3 & - & $16.9(5 / 1) \ddagger$ & 22.3 & 23.5 & 23.3 & $20.7(9 / 30) \S$ & \\
\hline MOBAI 3 & - & $16.9(5 / 1) \ddagger$ & 22.3 & 23.5 & 23.3 & $20.7(9 / 30) \S$ & \\
\hline NECCI 3 & $7.0(4 / I) \ddagger$ & 15.5 & 22.0 & 23.1 & 23.2 & $20.5(9 / 30) \S$ & \\
\hline NEMCI 3 & - & $15.7(5 / I) \ddagger$ & 21.6 & 23.1 & 23.5 & $20.5(9 / 23) \S$ & \\
\hline NDARI 3 & - & $18.3(5 / 28) \ddagger$ & 19.6 & 7.6 & 20.7 & $16.9(9 / 23) \S$ & \\
\hline NDVCI 3 & - & $21.4(5 / 20) \ddagger$ & 18.7 & 21.4 & 20.8 & I $6.7(9 / 30) \S$ & \\
\hline
\end{tabular}

$\dagger$ Indicates sites with irrigation.

$\ddagger$ Indicates start date of data collection.

$\S$ Indicates end date of data collection. 


\section{MATERIALS AND METHODS}

During 2012 and 2013 a total of 12 field sites were chosen: two each year in Nebraska (NE), Missouri (MO), and North Dakota (ND) (Table 1). For each state, a site with expected high and moderate yield potential was chosen. Nebraska sites in 2012 and 2013 were fully irrigated. In 2012, Missouri sites received limited irrigation to keep the crop alive during drought conditions. Due to the severe drought along with uneven sprinkler irrigation following the in-season $\mathrm{N}$ application, one MO site in 2012 was considered to be unreliable and was discarded, therefore data are presented and discussed for only 11 sites. Growing season monthly precipitation and irrigation totals and average temperature are presented for each site in Table 2. Each experimental site contained four replications of 16 treatments arranged in a randomized complete block design. Two hybrids were selected for each site; those used in $\mathrm{MO}$ and NE were characterized by having a high or low drought score, with low drought score indicating the crop is more susceptible to drought. Each hybrid was planted at two seeding rates (Table 3). Four $\mathrm{N}$ treatments were implemented: unfertilized check, nonlimiting $\mathrm{N}$ reference, sensor-based, and model-based; these are hereafter referred to as check, reference, sensor, and model, respectively. The check received no $\mathrm{N}$ during the study. The reference received an $\mathrm{N}$ rate considered to be non-limiting to yield for the site. The reference rate was $269 \mathrm{~kg} \mathrm{ha}^{-1}$ for MO sites, $224 \mathrm{~kg} \mathrm{ha}^{-1}$ for ND sites, and ranged from 268 to $280 \mathrm{~kg} \mathrm{ha}^{-1}$ for NE sites. The sensor and model treatments received an initial $\mathrm{N}$ rate and an in-season $\mathrm{N}$ rate. The initial $\mathrm{N}$ rate for sensor and model treatments was $56 \mathrm{~kg} \mathrm{ha}^{-1}$ for MO sites, $0 \mathrm{~kg} \mathrm{ha}^{-1}$ for ND sites, and $84 \mathrm{~kg} \mathrm{ha}^{-1}$ for NE sites. A researcher with previous experience in each state determined the initial $\mathrm{N}$, with a goal of selecting an $\mathrm{N}$ rate that would not cause unrecoverable stress before the in-season $\mathrm{N}$ application. In-season $\mathrm{N}$ applications were applied to both model and sensor treatments at the time of crop canopy sensing, typically at the V8-V10 growth stage. Nitrogen uptake is maximized and $\mathrm{N}$ loss reduced when fertilizer is applied at the beginning of the rapid crop growth period, roughly between the $\mathrm{V} 9$ and V18 growth stage for corn (Scharf and Lory, 2006). In-season N applications were applied to the sensor treatment using recommendations from the Holland and Schepers sensor algorithm (Holland and Schepers, 2010), and to the model treatments using Maize-N (Yang et al., University of Nebraska-Lincoln, 2008).
Crop canopy reflectance data were collected from all treatment plots before the in-season $\mathrm{N}$ fertilizer application of sensor and model treatments. Data were collected using a RapidSCAN CS-45 Handheld Crop Sensor (Holland Scientific, Lincoln, NE) oriented in the nadir position and at least $0.6 \mathrm{~m}$ above the crop canopy. The sensor uses a polychromatic modulated light source and three photodetector measurement channels: 670,730 , and $780 \mathrm{~nm}$. Sensor values were recorded at $1 \mathrm{~Hz}$ and walking speed through the plots resulted in collection of one sensor reading about every $25 \mathrm{~cm}$ for a total of about 61 readings for each row. Two rows per plot were scanned, from which an average NDRE value was calculated. This study used the NDRE index (Eq. [1]) as it includes wavelengths that have been previously found to be sensitive to chlorophyll content of plants (Scharf and Lory, 2009).

$$
\mathrm{NDRE}=\left(\mathrm{R}_{\mathrm{NIR}}-\mathrm{R}_{\mathrm{RED} \mathrm{EDGE}}\right) /\left(\mathrm{R}_{\mathrm{NIR}}+\mathrm{R}_{\mathrm{RED} \mathrm{EDGE}}\right)[1]
$$

where $\mathrm{R}_{\mathrm{NIR}}=$ near-infrared reflectance $(780 \mathrm{~nm})$ and $\mathrm{R}_{\mathrm{RED} \mathrm{EDGE}}=$ red edge reflectance $(730 \mathrm{~nm})$.

The sufficiency index (SI) value was calculated for each plot by dividing the NDRE from the sensor treatment by the NDRE from the corresponding reference treatment of the same hybrid and plant population for each replication. The SI was then used in the modified algorithm by Holland and Schepers (2010, modified 2012) to determine an $\mathrm{N}$ application rate. In addition to the user providing the SI, this algorithm requires the user to input three other variables: crop growth stage, amount of $\mathrm{N}$ fertilizer applied before crop sensing and in-season fertilization, and user-predicted ONR. For this study, the user-predicted ONR was calculated using algorithms developed by the University of Nebraska-Lincoln and North Dakota State University for producers applying a uniform rate of N (Shapiro et al., 2003; D.W. Franzen, personal communication, 2013).

For the Maize-N model treatments, soil properties, weather data, and site management information were input into the software. Among other soil properties, the model requires that the user input percent soil organic carbon (SOC). Percent SOM was determined for all sites using the loss on ignition (LOI) method and these values were converted to percent SOC. The model uses this information to estimate $\mathrm{N}$ mineralization from SOM.

Table 3. Hybrid and planting population treatments for each site in Nebraska (NE), Missouri (MO), and North Dakota (ND).

\begin{tabular}{|c|c|c|c|c|}
\hline \multirow[b]{2}{*}{ Site ID } & \multicolumn{2}{|c|}{ Hybridt } & \multicolumn{2}{|c|}{ Planting population } \\
\hline & $A$ & $B$ & Low rate & High rate \\
\hline & & & $\longrightarrow$ & $\overline{-}$ \\
\hline MOLTI2 & Pioneer 33D49 & Pioneer I498 & 76,601 & 101,311 \\
\hline MOTRI3 & Pioneer 33D49 & Pioneer 1498 & 76,601 & $|0|, 31 \mid$ \\
\hline MOBAI 3 & Pioneer 33D49 & Pioneer 1498 & 76,601 & $|0|, 3 \mid 1$ \\
\hline NDDNI 2 & Pioneer 39N99 & Pioneer 8906 HR & 79,072 & 103,782 \\
\hline NDVCI2 & Pioneer 39N99 & Pioneer 8906 HR & 79,072 & 103,782 \\
\hline NDAR I 3 & Pioneer 39N95 AM & Pioneer 8906 HR & 79,072 & 103,782 \\
\hline NDVCI3 & Pioneer 39N95 AM & Pioneer 8906 HR & 79,072 & 103,782 \\
\hline $\mathrm{NECCI} 2$ & Pioneer 33D49 & Pioneer I498 & 79,072 & 103,782 \\
\hline NEMCI 2 & Pioneer 33D49 & Pioneer I498 & 79,072 & 103,782 \\
\hline NECCI3 & Pioneer 33D53 AM & Pioneer I498 AM & 79,072 & 103,782 \\
\hline NEMCI 3 & Pioneer 33D53 AM & Pioneer I498 AM & 79,072 & 103,782 \\
\hline
\end{tabular}

† For NE and $\mathrm{MO}$ sites, hybrid $\mathrm{A}$ has a lower drought score and hybrid $\mathrm{B}$ has a higher drought score. 
Maize-N Version 2008.1.0, which was used for the 2012 growing season, did not take into account in-season 2012 weather data to determine mineralized $\mathrm{N}$ (only historic, long-term weather data were used to predict mineralization). For 2013, Version 2013.2.0 was used which contains updates allowing the model to utilize current-year weather data to estimate the amount of $\mathrm{N}$ mineralized from the termination of the previous crop to the time in-season $\mathrm{N}$ application occurs. Long-term weather data was then used to predict mineralization of $\mathrm{N}$ for the remainder of the season, based on historical trends. One simulation run was made for each unique hybrid and population treatment combination. For site MOTR13, the economically optimum $\mathrm{N}$ rate and in-season $\mathrm{N}$ recommendation were incorrectly reduced by $18 \mathrm{~kg} \mathrm{~N} \mathrm{ha}^{-1}$ due to an error in $\mathrm{N}$ credits applied for the model input values.

In-season $\mathrm{N}$ was applied to model and sensor treatments using different $\mathrm{N}$ sources and application methods for each site. For the model treatments, the same $\mathrm{N}$ rate was applied to a given treatment (hybrid and population combination) in all replications of a given site. In contrast, for the sensor treatments, $\mathrm{N}$ rate was applied to each hybrid and population treatment based on the $\mathrm{N}$ need indicated in each replication. It should be noted that although the sensor method varied the rate on a finer spatial scale (among replications in this case), the model approach does have the ability to incorporate a variable rate approach, but on a coarser spatial scale. The model allows for adjustments in $\mathrm{N}$ recommendation due to soil type and SOC. However, for the size of plots in the study, spatially dense SOC data was not available to trigger such a change within the treatment area, nor were soil texture variations great enough to adjust in the model. In MO, Super-U (46\% N granular urea with urease and nitrification inhibitors) was broadcast by hand application. For NE sites, UAN (32\%) was surface applied in bands between crop rows. Similarly, at ND sites, UAN (28\%) was applied in bands using a walk behind applicator with streaming drop nozzles. Upon physiological maturity, corn from all plots was harvested either by hand or using small plot combines. Partial factor productivity for nitrogen $\left(\mathrm{PFP}_{\mathrm{N}}\right)$ was calculated by dividing grain yield by total fertilizer $\mathrm{N}$ rate. Agronomic efficiency (AE) was calculated by taking the difference in yield between the fertilized treatment and the check and dividing by total $\mathrm{N}$ application. A comparison of net profit across the $\mathrm{N}$ strategies was made by assuming corn could be sold for US $\$ 0.20 \mathrm{~kg}^{-1}\left(\$ 5.00 \mathrm{bu}^{-1}\right)$ and that $\mathrm{N}$ fertilizer costs $\$ 1.10 \mathrm{~kg}^{-1}\left(\$ 0.50 \mathrm{lb}^{-1}\right)$. The yield for each plot was multiplied by the market price and the amount of fertilizer applied to each plot was multiplied by the unit cost of fertilizer. Fertilizer cost was subtracted from grain price to determine the net return in $\$ \mathrm{ha}^{-1}$. The data were analyzed using the GLIMMIX procedure in Statistical Analysis System (SAS) 9.2 (SAS Institute, 2008). Mean separation test was done using Fisher's LSD $(\alpha=0.05)$.

To estimate the agronomic ONR, a linear-plateau response curve representing yield as a function of $\mathrm{N}$ rate was derived using the $\mathrm{N}$ rates and corresponding yields; unique linearplateau relationships were created for each site. The high $\mathrm{N}$ reference was assumed non-limiting for $\mathrm{N}$ and thus used to generate the plateau of the response relationship. Tests of statistical differences $(\alpha=0.05)$ due to plant population and hybrid for the reference treatments were determined using the GLM procedure in SAS. If a significant difference in plateau yield occurred for plant population or hybrid, then individual means for these treatments were used to create separate plateaus to reflect different mean values. If no statistically significant differences were found for plant population or hybrid for the reference, the overall mean of the reference was used to define the plateau. For the linear part of the linear-plateau relationship, the check, sensor, and model treatment $\mathrm{N}$ rates and associated yield response results were used. The yield of the check established the linear model intercept. The model and sensor $\mathrm{N}$ rate and yields were utilized to determine the slope of the linear function. Stepwise linear regression $(\alpha=0.05)$ was used to test for significant intercept and slope differences, as impacted by plant population and/or hybrid treatments. This procedure allowed for unique linear models to be generated when significant differences occurred with no $\mathrm{N}$ and/or with $\mathrm{N}$ additions. Optimum $\mathrm{N}$ rate for all unique combinations of the linear-plateau models was determined by solving for the joint of the linear-plateau model, as follows:

$$
\mathrm{ONR}=(\text { plateau }-a) / b
$$

where $a=$ the linear regression intercept and $b=$ the linear regression slope.

Using this approach, ONR was determined for 8 of the 11 sites. A reliable estimate of ONR could not be determined for the remaining three sites due to lack of $\mathrm{N}$ response primarily because of drought. For the eight sites, ONR was compared graphically to the actual $\mathrm{N}$ applied for both the model and sensor treatments to examine which treatment best predicted ONR. Linear regressions of ONR relative to both the model and sensor $\mathrm{N}$ recommendation approaches were determined using the REG procedure in SAS. The intercept was set to 0. Adjusted coefficient of determination values $\left(r^{2}\right)$ are presented.

\section{RESULTS AND DISCUSSION}

\section{In-Season Nitrogen Recommendations}

In-season $\mathrm{N}$ applications recommended by the Maize-N model and Holland and Schepers sensor-based algorithm are summarized for each site, averaged across hybrid and population treatments (Table 4). For the majority of sites, in-season $\mathrm{N}$ rates for the model approach were higher than in-season $\mathrm{N}$ rates for the sensor approach. Over all sites, the crop model approach recommended on average $60.7 \mathrm{~kg} \mathrm{~N} \mathrm{ha}^{-1}$ more than the canopy sensing approach. For one site, NECC12, no in-season N application was recommended using the sensor approach. At only two sites did the sensor approach recommend more in-season $\mathrm{N}$ than the crop modeling approach (sites MOBA13 and NDVC13). The model approach did not recommend any $\mathrm{N}$ application at NDVC13 largely due to high levels of soil nitrate being input into the model. The relatively low recommended $\mathrm{N}$ rates from canopy sensing $\left(\overline{\mathrm{x}}=43.5 \mathrm{~kg} \mathrm{ha}^{-1}\right)$ indicates NDRE values of the corn to be fertilized was not much different than NDRE values of the reference. For site MOTR13, the in-season $\mathrm{N}$ rate for the model approach was erroneously reduced by $18 \mathrm{~kg} \mathrm{ha}^{-1}$. This resulted in the total $\mathrm{N}$ rate for the model treatments being $13 \mathrm{~kg} \mathrm{ha}^{-1}$ lower than the $\mathrm{N}$ rate for the reference rather than $5 \mathrm{~kg} \mathrm{ha}^{-1}$ higher than the reference $\mathrm{N}$ rate.

Maize- $\mathrm{N}$ recommendation of EONR is, among other factors, dependent on the model's ability to predict $\mathrm{N}$ mineralization 
Table 4. In-season $\mathrm{N}$ application rates for model and sensor $\mathrm{N}$ strategies for all site-years. Nitrogen strategy main effects of grain yield, agronomic efficiency, partial factor productivity of $\mathrm{N}$, and net return for all site-years in Nebraska (NE), Missouri (MO), and North Dakota (ND).

\begin{tabular}{|c|c|c|c|c|c|c|c|c|c|c|c|}
\hline$\stackrel{\mathrm{N}}{\text { treatments }}$ & $\mathrm{NEMCI} 2$ & $\mathrm{NECCI} 2$ & MOLTI2 & NDDNI 2 & NDVCI 2 & NEMCI 3 & $\mathrm{NECCI} 3$ & MOTRI3 & MOBAI3 & NDARI3 & NDVCI 3 \\
\hline & \multicolumn{11}{|c|}{ In-season $\mathrm{N}$ application rate } \\
\hline & & & & & & - $\mathrm{kg} \mathrm{ha}^{-1}$ & & & & & \\
\hline Model & 81 & 25 & 76 & 198 & 198 & 120 & 103 & 200 & 54 & 83 & 0 \\
\hline \multirow[t]{3}{*}{ Sensor } & 13 & 0 & 40 & 82 & 47 & 35 & 21 & 35 & 74 & 59 & 59 \\
\hline & \multicolumn{11}{|c|}{ Grain yield } \\
\hline & & & & & & 8 & & & & & \\
\hline Check & $14.3 \mathrm{~b} \dagger$ & $15.0 \mathrm{a}$ & $3.27 b$ & $4.15 b$ & $7.55 b$ & $7.76 \mathrm{c}$ & $9.84 b$ & $5.1 \mathrm{Id}$ & $2.4 \mathrm{lc}$ & 7.1 la & $5.63 a$ \\
\hline Model & $15.2 \mathrm{a}$ & I5.Ia & $6.04 a$ & $5.16 \mathrm{ab}$ & $8.49 \mathrm{ab}$ & $13.8 \mathrm{a}$ & $12.6 \mathrm{a}$ & $15.1 b$ & $7.25 b$ & $7.93 a$ & $6.05 \mathrm{a}$ \\
\hline Sensor & $15.8 \mathrm{a}$ & $15.8 \mathrm{a}$ & $5.66 a$ & $4.53 b$ & $7.74 b$ & $12.4 \mathrm{~b}$ & $12.5 \mathrm{a}$ & $11.6 \mathrm{c}$ & $7.74 a$ & $7.66 \mathrm{a}$ & $6.79 \mathrm{a}$ \\
\hline \multirow[t]{3}{*}{ Reference } & $15.4 \mathrm{a}$ & $15.5 \mathrm{a}$ & $5.66 \mathrm{a}$ & $5.85 \mathrm{a}$ & $9.25 \mathrm{a}$ & $13.9 \mathrm{a}$ & $12.9 \mathrm{a}$ & $16.0 \mathrm{a}$ & $8.02 \mathrm{a}$ & $7.55 \mathrm{a}$ & $7.09 \mathrm{a}$ \\
\hline & \multicolumn{11}{|c|}{ Agronomic efficiency } \\
\hline & & & & & - kg gra & ain increase & $\mathrm{kg} \mathrm{N}^{-1}$ & & & & \\
\hline Model & $5.74 b$ & $1.15 a$ & $20.9 \mathrm{a}$ & $6.27 \mathrm{a}$ & $4.52 \mathrm{a}$ & $29.5 b$ & I5.0b & $38.7 b$ & $44.1 \mathrm{a}$ & $9.94 a$ & - \\
\hline Sensor & $15.8 \mathrm{a}$ & $9.15 a$ & $27.5 \mathrm{a}$ & $14.5 \mathrm{a}$ & $7.75 \mathrm{a}$ & $38.9 a$ & $26.3 a$ & $77.7 \mathrm{a}$ & $41.2 \mathrm{a}$ & $8.19 a$ & $19.8 \mathrm{a}$ \\
\hline \multirow[t]{3}{*}{ Reference } & $4.06 c$ & $1.59 \mathrm{a}$ & $8.92 b$ & $8.61 \mathrm{a}$ & $7.69 a$ & $22.8 \mathrm{c}$ & $10.9 c$ & $39.3 b$ & $20.0 b$ & $1.93 \mathrm{a}$ & $6.52 b$ \\
\hline & \multicolumn{11}{|c|}{ Partial factor productivity of $\mathrm{N}$} \\
\hline & & & & & & $\mathrm{kg}$ grain $\mathrm{kg}$ & $v^{-1}$ & & & & \\
\hline Model & $92.20 \mathrm{~b}$ & $139.5 b$ & $45.40 b$ & $25.96 b$ & $42.79 b$ & $67.49 b$ & $67.60 \mathrm{~b}$ & $59.45 b$ & $65.88 a$ & $96.30 \mathrm{~b}$ & - \\
\hline Sensor & $164.6 \mathrm{a}$ & 187.4a & $59.34 a$ & $47.86 a$ & I44.5a & $106.8 \mathrm{a}$ & $121.3 a$ & $140.7 \mathrm{a}$ & $59.85 b$ & $133.4 \mathrm{a}$ & II6.4a \\
\hline \multirow[t]{3}{*}{ Reference } & $57.01 \mathrm{c}$ & $55.05 c$ & $20.13 b$ & $25.97 b$ & $4 I .24 b$ & $51.64 c$ & $45.95 c$ & $57.10 \mathrm{~b}$ & $28.57 c$ & $33.6 \mathrm{lc}$ & $31.57 b$ \\
\hline & \multirow{2}{*}{\multicolumn{11}{|c|}{ Net return }} \\
\hline & & & & & & & & & & & \\
\hline Check & $2803 b$ & 2949ab & $618 c$ & $816 a$ & $1480 \mathrm{a}$ & $1525 c$ & $1932 c$ & $1003 d$ & $472 c$ & $1398 a$ & II05a \\
\hline Model & $2808 b$ & $285 \mathrm{Ibc}$ & $994 a$ & $794 a$ & $1446 a$ & $2485 a$ & $2273 \mathrm{ab}$ & $269 \mathrm{lb}$ & I 304ab & $1466 a$ & $1189 a$ \\
\hline Sensor & $2989 a$ & $3007 a$ & $974 a$ & $802 a$ & $1462 a$ & $2307 b$ & $2348 a$ & $2180 c$ & $1376 a$ & $1439 a$ & $1268 \mathrm{a}$ \\
\hline Reference & $2722 b$ & $2728 c$ & $80 \mathrm{lb}$ & $899 a$ & I573a & $2438 a$ & $2226 b$ & $284 \mathrm{la}$ & $1267 b$ & $1236 \mathrm{~b}$ & $1146 a$ \\
\hline
\end{tabular}

† Within columns, means followed by the same letter are not significantly different according to LSD (0.05).

from SOM. Nitrogen mineralization was expected to vary by site because each site had unique SOM content and weather conditions controlling $\mathrm{N}$ mineralization. The predicted $\mathrm{N}$ mineralization from SOM is shown for the two different versions of Maize $\mathrm{N}$ for all field trials of this study (Fig. 1). In general, increases in site SOM resulted in increased predicted $\mathrm{N}$ mineralization (Myrold and Bottomley, 2008). Two exceptions were the two 2012 ND sites where predicted $N$ from mineralization was $<30 \mathrm{~kg} \mathrm{~N} \mathrm{ha}^{-1} \mathrm{yr}^{-1}$. Although the $2012 \mathrm{ND}$ sites had some of the highest SOM measured, the Maize-N estimated N contribution from SOM mineralization was the lowest of all sites; the result of this lower $\mathrm{N}$ credit was higher $\mathrm{N}$ recommendations for the 2012 ND sites. These results demonstrate how the crop model accounted for factors influencing mineralization such as temperature and the duration from the end of the last crop to the completion of the current crop season.

\section{Nitrogen Strategy Main Effects on Yield, Partial Factor Productivity of Nitrogen, Agronomic Efficiency, and Profit}

The effects of $\mathrm{N}$ recommendation strategies are presented for yield, $\mathrm{PFP}_{\mathrm{N}}$, and $\mathrm{AE}$ (Table 4 ). In a few cases, interactions were observed between $\mathrm{N}$ recommendation strategy and hybrid and/ or population, but due to lack of any meaningful agronomic

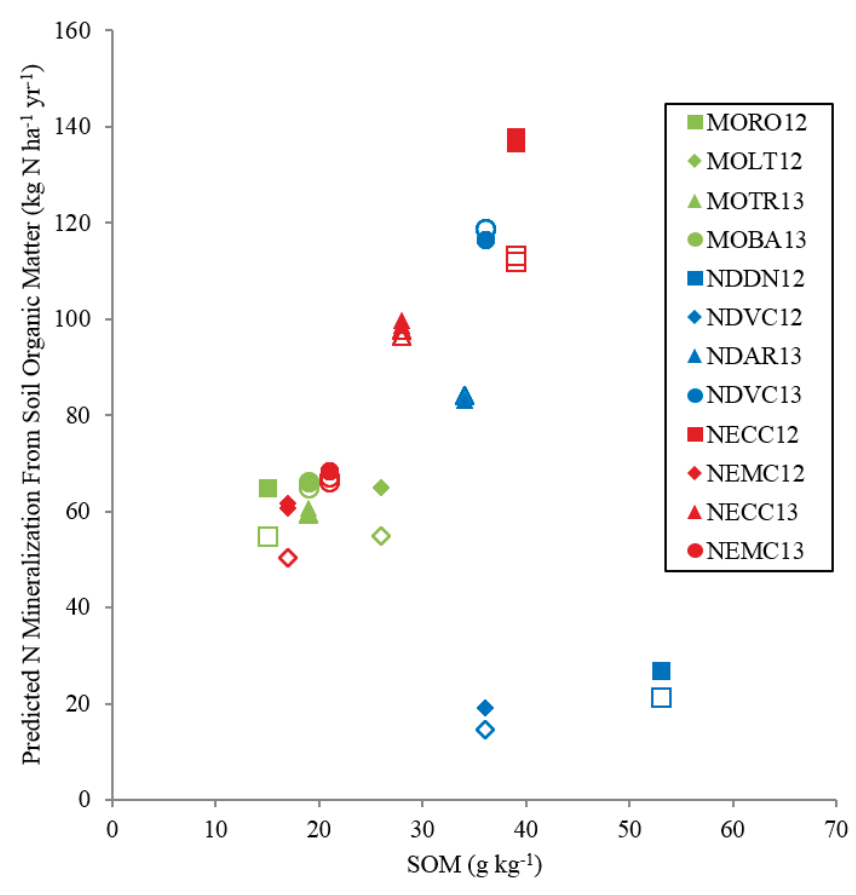

Fig. I. Comparison of site soil organic matter (SOM) to the predicted $\mathrm{N}$ mineralization from SOM using Maize- $\mathrm{N}$ Version 2008.I.0 (open symbols) and 2013.2.0 (filled symbols) for Missouri (MO), North Dakota (ND), and Nebraska (NE) sites. 
explanations among these interactions, only the main effects of $\mathrm{N}$ recommendation strategy are presented. As would be expected, yield was lowest with no $\mathrm{N}$ fertilization (average over all sites: $7.4 \mathrm{Mg} \mathrm{ha}^{-1}$ ). Exceptions included NECC12, NDAR13, and NDVC13 sites where results show little $\mathrm{N}$ was needed for optimal yield. The reference rate generally produced the highest yields (average over all sites: $10.6 \mathrm{Mg} \mathrm{ha}^{-1}$ ). The sensor approach produced yields lower than the modeling approach at two sites (NEMC13, MOTR13) and yields lower than the reference at four sites (NDDN12, NDVC12, NEMC13, MOTR13). The model approach produced yields lower than the sensor approach at one site (MOBA13) and yields lower than the reference at two sites (MOTR13 and MOBA13).

For 1 site-year (MOTR13), growing conditions were exceptional and both the model and sensor $\mathrm{N}$ rates limited yield. However, at this site the in-season $\mathrm{N}$ rate for the model approach was erroneously reduced by $18 \mathrm{~kg} \mathrm{ha}^{-1}$. With the model approach only yielding $0.9 \mathrm{Mg} \mathrm{ha}^{-1}$ less than the reference, the correct $\mathrm{N}$ rate may have resulted in yield similar to the reference. At the ND sites in 2013, response to any $\mathrm{N}$ application was nonexistent which is attributed to factors other than $\mathrm{N}$ generally limiting crop production. High yields for the check treatment at the NE sites in 2012 are explained by unusually high rates of mineralization of $\mathrm{N}$ in the spring before planting, but after pre-plant soil samples accounted for residual soil $\mathrm{N}$, which reduced response to fertilizer N. A comprehensive study in NE (Dobermann et al., 2011) found $\mathrm{N}$ mineralized from SOM during the growing season ranged from 15 to $35 \mathrm{~kg} \mathrm{Mg}^{-1} \mathrm{SOM}$. At these two sites, the sensor approach had a lower $\mathrm{N}$ rate than the model approach; however yield was not significantly different. Under these conditions, canopy sensing worked well and $\mathrm{N}$ application was appropriately reduced, resulting in no yield decrease compared with the reference. Over all site years combined, the model did a better job of protecting yield potential compared to the sensor approach with the Holland and Schepers 2010 algorithm. In part, this is due to the version of the Holland and Schepers algorithm used, which allowed the $\mathrm{N}$ recommendation to be $0 \mathrm{~kg} \mathrm{ha}^{-1}$. More recent versions of the Holland and Schepers algorithm maintains a base recommendation even when crop stress is not detected. While maintaining a base recommendation above $0 \mathrm{~kg} \mathrm{ha}^{-1}$ may have improved yields at some sites, it would have also reduced the success of the sensor approach at NECC12 where no N application was recommended.

Agronomic efficiency and $\mathrm{PFP}_{\mathrm{N}}$ were generally lower with the reference than the two $\mathrm{N}$ management approaches that were evaluated (Table 4). This would be expected since the amount of $\mathrm{N}$ applied for the reference was expected to be more than the crop needed. Agronomic efficiency of the sensor approach tended to be higher than the model approach; however, it was only significantly higher at four sites (no comparison can be made for NDVC13 as there was no $\mathrm{N}$ application for the model approach). Similarly, the sensor approach had a higher $\mathrm{PFP}_{\mathrm{N}}$ than the model approach at 9 of 10 sites (again no comparison can be made for NDVC13). For Nebraska sites this difference was attributed to high levels of $\mathrm{N}$ mineralization resulting in high yields, even for the check treatment that received no $\mathrm{N}$ application. The sensor approach appropriately reduced the in-season $\mathrm{N}$ recommendation at these sites, while the model did not. It should be noted that the model Version
2008.1.0 was used in 2012, which lacked the capability of adjusting for the effect of weather on mineralization up to the time of fertilization. Use of the updated Version 2013.2.0 in this case would have improved the in-season $\mathrm{N}$ recommendation by appropriately lowering the $\mathrm{N}$ rate (for all sites and treatment combinations collectively, Version 2013.2.0 generated an $\mathrm{N}$ rate that ranged from 0 to $36 \mathrm{~kg}$ lower and averaged $9 \mathrm{~kg}$ lower than Version 2008.1.0). For NEMC12 the rate with the updated version would have still been higher than the sensor rate, but for NECC12 the updated version would have resulted in an in-season $\mathrm{N}$ rate equal to the $\mathrm{N}$ rate prescribed by the sensor approach and therefore would have likely had a $\mathrm{PFP}_{\mathrm{N}}$ equal to that of the sensor approach. Overall, when examining $\mathrm{PFP}_{\mathrm{N}}$, the sensor approach is consistently higher than the model approach; this is likely due to the frequently lower $\mathrm{N}$ rates recommended by the sensor approach than the model approach. This is consistent with findings by Roberts et al. (2010) that documented higher $\mathrm{N}$ fertilizer recovery efficiency for treatments with lower $\mathrm{N}$ fertilizer application rates. However, because the treatment with the highest $\mathrm{PFP}_{\mathrm{N}}$ often has the lowest $\mathrm{N}$ rate, in many cases there may be a corresponding yield reduction compared to treatments with a lower $\mathrm{PFP}_{\mathrm{N}}$ but higher $\mathrm{N}$ rate. For this reason, $\mathrm{PFP}_{\mathrm{N}}$ should not be solely considered as an evaluation of the effectiveness of an $\mathrm{N}$ management strategy. Higher $\mathrm{PFP}_{\mathrm{N}}$ is desirable within a context where yield is not negatively impacted.

Net return was used to evaluate profitability of the model and sensor treatments (Table 4). Net returns for model and sensor treatments were equivalent in 7 of the 11 site-years. The sensor approach was significantly more profitable than the model at two sites (NEMC12 and NECC12) and more profitable than the reference at six sites. The increased profitability of the sensor approach over the model approach for these two NE sites was due to lower in-season $\mathrm{N}$ recommendations for the sensor $\mathrm{N}$ strategy and comparable yields. However, as was previously mentioned, use of the updated version of the Maize-N model would result in lower $\mathrm{N}$ recommendations for these two sites. For NECC12 the $\mathrm{N}$ recommendation would be identical to that of the sensor, and the difference in profitability between the model and sensor approaches at these sites would be expected to be nonexistent. For NEMC12, the N recommendation would still be higher than that of the sensor, but the difference in profitability between the model and sensor approaches would be expected to be decreased. The model approach was significantly more profitable than the sensor at two sites (NEMC13 and MOTR13) and more profitable than the reference at two sites. One site (MOTR13) had a large decrease in profitability for both the model (loss of $\$ 150 \mathrm{ha}^{-1}$ ) and the sensor (loss of $\$ 661 \mathrm{ha}^{-1}$ ) compared to the reference; this decrease in profit was due to insufficient $\mathrm{N}$ rate for the model and sensor treatments. Over all site-years combined, there was not a clear trend for profitability of these varying approaches.

In summary, there were six sites where the sensor treatment had yields that were not significantly lower than the reference treatment and had the highest $\mathrm{PFP}_{\mathrm{N}}$ (NEMC12, NECC12, MOLT12, NECC13, NDAR13, and NDVC13). In general, this situation occurred where the site was not highly responsive to $\mathrm{N}$ applications. This may be due to unpredictable conditions resulting in reduced yield, such as drought, or conditions resulting in $\mathrm{N}$ being available from other sources such as 
residual soil $\mathrm{N}$, irrigation water, or through $\mathrm{N}$ mineralization of SOM. Dry conditions resulted in lower yields for MOLT12, NDAR13, and NDVC13, therefore introducing a more limiting factor (water) and reducing $\mathrm{N}$ requirements for these sites. In the case of NEMC12 and NECC12, high N mineralization and lack of conditions contributing to $\mathrm{N}$ loss was suspected, resulting in these sites being less responsive to fertilizer $\mathrm{N}$. In the case of NEMC12 and NECC12 sites it is clear the sensor performed better as it recommended lower $\mathrm{N}$ rates, had higher yield, greater profit, and greater NUE. In 2013, the model performed better at sites NEMC13 and MOTR13 where the model approach had significantly higher yields and profitability than the sensor approach. At these site yields were high and the sensor approach did not provide enough $\mathrm{N}$ to maximize yields.

\section{Evaluating Nitrogen Management Approaches with Optimal Nitrogen Rate Determination}

The ONR values derived using the linear-plateau model are provided for each site in Table 5. Cerrato and Blackmer (1990) compared various models that are often used to describe the corn yield response to $\mathrm{N}$ fertilizer relationship. They concluded that the quadratic-plateau model best described the yield response to $\mathrm{N}$ fertilizer application in the study. The linear-plateau model predicted maximum yields similar to the quadratic-plateau model, however at the point of inflection, they found yields may be overestimated resulting in EONR values that are too low. While the authors acknowledge the limitation associated with the linear-plateau model, it was used due to the limited quantity and range of $\mathrm{N}$ rates available to model the yield response to $\mathrm{N}$ fertilizer relationship. Where significant differences due to plant population and/or hybrid occurred, ONR was adjusted accordingly. For three sites (NDDN12, NDVC12, and NDVC13) for some or all treatment combinations there was no $\mathrm{N}$ fertilizer response due to factors such as drought, therefore these sites were eliminated from this analysis. Sites NECC12 and NEMC12 were also non-responsive to fertilizer for some or all treatment combinations. However, this is attributed to high levels of $\mathrm{N}$ mineralization before the growing season, therefore these sites were included in the subsequent analysis.

Using the linear-plateau estimated ONR, the total $\mathrm{N}$ applied by both the model and sensor treatment approaches can be compared. Figure 2 illustrates the relationship between the estimated ONR and the total $\mathrm{N}$ applied using either the sensor or modeling strategy. The diagonal line represents the location on the graph where total $\mathrm{N}$ recommended and applied matches the linear-plateau estimated ONR. Points falling below this line are sites where the total $\mathrm{N}$ applied was in excess of the optimum, and points falling above this line are sites where the total $\mathrm{N}$ applied was less than the calculated optimum. Points at a greater distance from the line indicate greater variation from the estimated ONR. A linear regression of the data points with an intercept of 0 was fit and is depicted with a dashed line on each graph along with the coefficient of determination.

The Maize-N model most closely approximates the linearplateau estimated ONR over these sites and tended toward over-recommendation of $\mathrm{N}(y=0.851 x)$. Additionally, the Maize-N model deviated less from ONR than the sensor approach, as indicated by the coefficient of determination. The sensor approach recommended $\mathrm{N}$ applications that tended to be lower than the linear-plateau estimated ONR, resulting in under-application of $\mathrm{N}$ and consequential yield loss. It is important to remember that the results of the sensor approach are dependent on the algorithm used to convert sensor reflectance measurements into an $\mathrm{N}$ recommendation rate (in this case the Holland and Schepers 2010 sensor algorithm). Alternative or modified sensor algorithms should be evaluated to determine which algorithms produce the best results for specific geographic locations. Additionally, $\mathrm{N}$ recommendations would ideally be closer to the ONR than they were in this analysis, pointing to the need for further improvements in both the model and sensor approaches.

\section{Effects of Plant Populations on Sufficiency Index (Normalized Difference Red Edge) and Resulting Nitrogen Recommendations}

Plant population has the potential to affect crop canopy sensor readings and consequently $\mathrm{N}$ recommendation rates. However, previous work showed that reflectance differences among hybrids had minimal impact on fertilizer $\mathrm{N}$ recommendations (Sheridan et al., 2012), therefore having a reference strip of the same hybrid may not be critical. With this research we explored whether reference strips of differing plant populations are important in the determination of final in-season $\mathrm{N}$ recommendation. Because variable seeding rates are sometimes implemented in commercial crop production, it is important to determine the impact on $\mathrm{N}$ fertilizer recommendation when plant population is different between the reference strip and the portion of the field receiving in-season $\mathrm{N}$ application. Since

Table 5. Optimum nitrogen rate (ONR) values derived using the linear-plateau model for sites in Missouri (MO), North Dakota (ND), and Nebraska (NE) in 2012 and 2013. Where significant differences in hybrid and plant population treatments occurred, unique linearplateau models were derived resulting in unique ONR values as shown.

\begin{tabular}{lccrc}
\hline \multicolumn{1}{c}{ Site ID } & Hybrid A, low population & Hybrid A, high population & Hybrid B, low population & Hybrid B, high population \\
\cline { 2 - 5 } MOLTI2 & 141 & 73 & 141 & 73 \\
MOTRI3 & 245 & 279 & 245 & 279 \\
MOBAI3 & 162 & 124 & 162 & 124 \\
NDARI3 & 45 & 45 & 45 & 45 \\
NECCI2 & 0 & 0 & 0 & 0 \\
NEMCI2 & 0 & 0 & 132 & 132 \\
NECCI3 & 184 & 234 & 138 & 176 \\
NEMCI3 & 172 & 172 & 215 & 215 \\
\hline
\end{tabular}



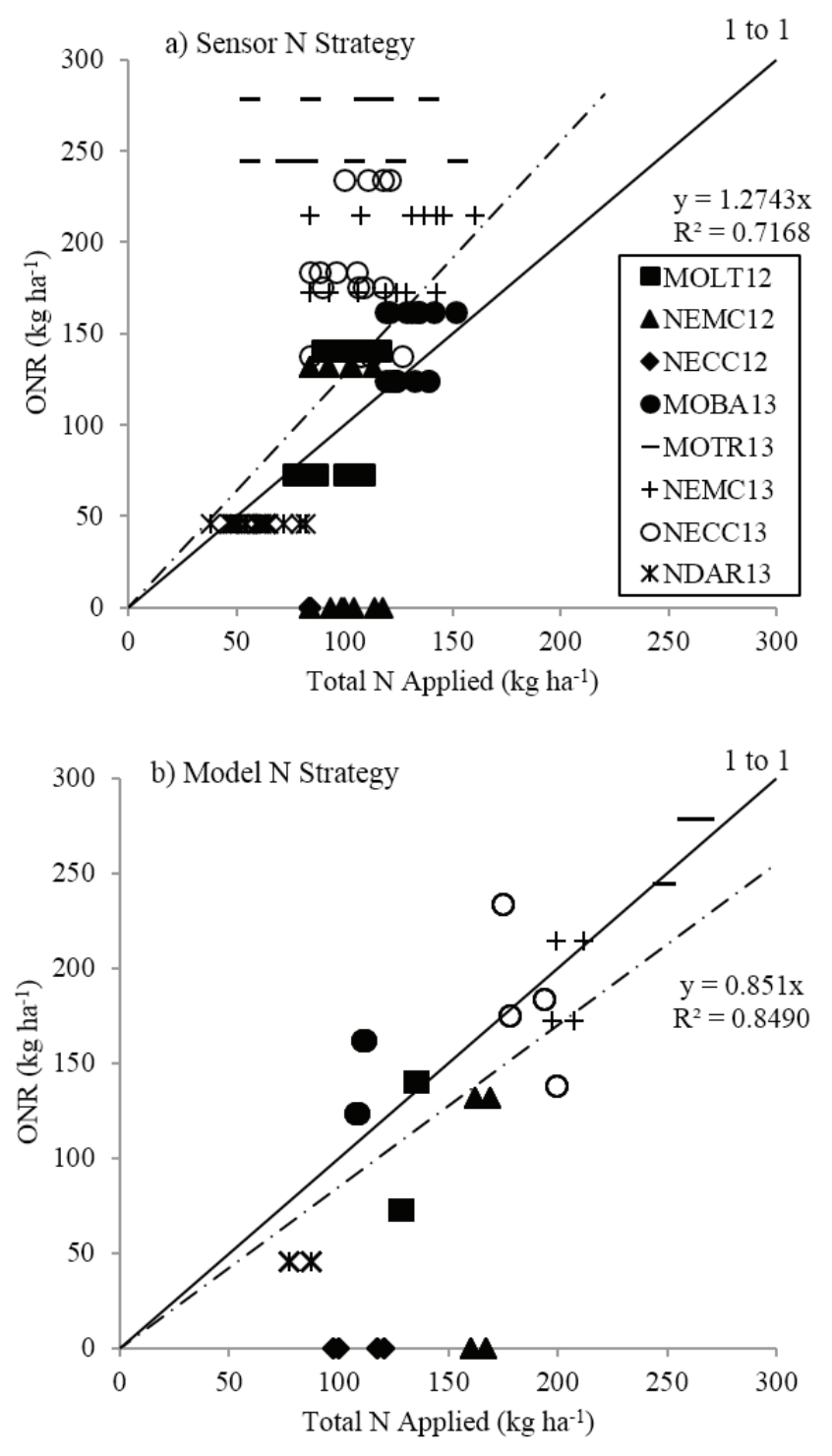

Fig. 2. Optimum $\mathrm{N}$ rate (ONR) derived from linear-plateau model compared to total $\mathrm{N}$ applied using (a) sensor $\mathrm{N}$ strategy and (b) model $\mathrm{N}$ strategy for sites in Missouri (MO), Nebraska (NE), and North Dakota (ND). Markers are data points from each hybrid and population combinations for individual replications.

plant biomass and leaf area index (LAI) are correlated with crop canopy reflectance, population differences may significantly influence vegetation index values, and consequently SI and resulting $N$ recommendation rates. Significant differences in NDRE were frequently seen for the plant population main effect (Table 6). The difference in recommended in-season $\mathrm{N}$ rate when there were significant NDRE differences for population at the time of fertilization was examined. A SI was generated using NDRE values of the high population treatment for the SI denominator (reference crop), and low population treatment for the SI numerator (target crop) and vice-versa. Population treatments with the same hybrid were used to generate SI, thus reflectance differences based on hybrid were not simultaneously investigated. The SI generated with a reference crop of differing population than the target crop population was then used in the Holland-Schepers sensor algorithm to generate the $\mathrm{N}$ rate recommendation. This was compared with the $\mathrm{N}$ recommendation for the target crop if the equivalent
Table 6. Plant population treatment means for normalized difference red edge (NDRE) and sufficiency index (SI) for sites in Nebraska (NE), Missouri (MO), and North Dakota (ND) in 2012 and 2013 where plant population main effect is significant at $P \leq 0.05$.

\begin{tabular}{|c|c|c|}
\hline Site ID & Low population & High population \\
\hline & \multicolumn{2}{|c|}{ NDRE at time of $\mathrm{N}$ application } \\
\hline $\mathrm{NECCI} 2$ & 0.3970 & 0.4037 \\
\hline NEMCI 2 & 0.3481 & 0.3682 \\
\hline MOLTI2 & 0.3783 & 0.3843 \\
\hline NDDNI 2 & 0.2269 & 0.2066 \\
\hline NDVCI 2 & 0.2925 & 0.3130 \\
\hline NECCI3 & 0.4268 & 0.4339 \\
\hline NEMCI3† & 0.3485 & 0.3570 \\
\hline MOTRI3 & 0.3681 & 0.3775 \\
\hline \multirow[t]{2}{*}{ NDVCI3 } & 0.2154 & 0.2278 \\
\hline & \multicolumn{2}{|c|}{ NDRE following application } \\
\hline $\mathrm{NECCI} 2$ & 0.4631 & 0.4590 \\
\hline NDDNI 2 & 0.3189 & 0.3009 \\
\hline \multirow[t]{2}{*}{ NECCI3 } & 0.4373 & 0.4438 \\
\hline & \multicolumn{2}{|c|}{$\underline{\text { SI at time of } \mathrm{N} \text { application }}$} \\
\hline NECCI3 & 0.9835 & 0.9668 \\
\hline \multirow[t]{2}{*}{ NEMCI 3} & 0.9345 & 0.8866 \\
\hline & \multicolumn{2}{|c|}{$\underline{\text { SI following application }}$} \\
\hline $\mathrm{NEMCI} 2$ & 0.9886 & 0.9738 \\
\hline NEMCI3† & 0.9527 & 0.9411 \\
\hline NDAR I 3 & 1.0082 & 0.9890 \\
\hline
\end{tabular}

† Indicates interaction between plant population and hybrid and/or $\mathrm{N}$ strategy is present at this site.

population treatment was used as a reference. Nitrogen rates when the same population and opposing population were used for the reference and target crop are shown in Table 7.

The magnitude of difference in recommended $\mathrm{N}$ rate incurred by using alternate populations for the SI ranged from 0 to $48.2 \mathrm{~kg} \mathrm{~N} \mathrm{ha}^{-1}$. In most cases, using a reference of higher population than the target crop resulted in increased $\mathrm{N}$ rates. This would be expected as the apparent biomass of the higher population reference would be greater, resulting in higher NDRE values and consequently lower SI for use in the $\mathrm{N}$ recommendation algorithm. Conversely, using a reference of lower population than the target crop resulted in decreased $\mathrm{N}$ recommendation. The NDDN12 site had an opposite response which is attributed to water stress at the time of sensing.

It is important to note that the difference of $\mathrm{N}$ recommendation rate reported here would be expected to increase as variation in plant population increased. In this study, population differences were at most 24,710 seeds $\mathrm{ha}^{-1}$. The practical significance of these $\mathrm{N}$ rate recommendation differences must be evaluated by the producer and be considered in accordance with the recommendation precision desired. Producers should be aware that using a higher plant population for the reference strip may result in greater $\mathrm{N}$ recommendations, and using a lower plant population for the reference strip may result in lower $\mathrm{N}$ recommendations. Those desiring to ensure that $\mathrm{N}$ recommendations are not limiting to crop yield should be advised to not use a reference strip of lower plant population than the remainder of the field. 
Table 7. Average $\mathrm{N}$ rate recommendations generated using sufficiency index (SI) with normalized difference red edge (NDRE) values from the same or different populations of target and reference crops. Fertilizer recommendations for NDRE values were used with Holland-Schepers algorithm for sensor N recommendations. Sites shown in Nebraska (NE), Missouri (MO), and North Dakota (ND) in 2012 and 2013 where significant population main effect differences in NDRE at the time of fertilizing occurred.

\begin{tabular}{|c|c|c|c|}
\hline Site ID & $\begin{array}{l}\text { Average } \mathrm{N} \text { rate with } \\
\text { matching population }\end{array}$ & $\begin{array}{c}\text { Average } \mathrm{N} \text { rate with } \mathrm{SI} \text { from high population } \\
\text { reference and low population target }\end{array}$ & $\begin{array}{l}\text { Average } \mathrm{N} \text { rate with } \mathrm{SI} \text { from low population } \\
\text { reference and high population target }\end{array}$ \\
\hline & 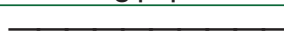 & $\mathrm{kg} \mathrm{N} \mathrm{ha} a^{-1}$ & \\
\hline $\mathrm{NECCI} 2$ & 0 & 0 & 0 \\
\hline NEMCI 2 & 13.1 & 27.7 & 0 \\
\hline MOLTI2 & 39.2 & 47.1 & 29.8 \\
\hline NDDNI 2 & 81.8 & 49.0 & 109.6 \\
\hline NDVCI 2 & 47.1 & 57.2 & 35.9 \\
\hline NECCI3 & 21.3 & 44.8 & 1.26 \\
\hline MOTRI3 & 34.8 & 58.3 & 13.5 \\
\hline NDVCI3 & 59.4 & 59.4 & 58.3 \\
\hline
\end{tabular}

\section{CONCLUSIONS}

Plant population in some cases had an impact on NDRE determined from crop canopy sensing. This indicates that it is desirable for the reference strip used for determination of SI to be of the same population as the target crop.

Over all site-years combined, yield was better protected by using the model approach than by using the sensor approach with the Holland and Schepers 2010 algorithm (model approach yielded lower than the reference at 2 of 11 sites compared to sensor approach which yielded lower than the reference at 4 of 11 sites). However, due to lower in-season $\mathrm{N}$ recommendations, the sensor approach was generally higher in NUE than the model approach. No clear trends in profitability were observed. In an ideal situation, $\mathrm{N}$ applications would be optimized without sacrificing yield. This clearly was the case for two NE sites in 2012 where the sensor approach appropriately reduced $\mathrm{N}$ application. This demonstrates how the sensor approach is unique in its ability to be responsive to in-season growing conditions. The latest version of the Maize-N model approach has some ability to do this, as $\mathrm{N}$ recommendations account for expected mineralization of $\mathrm{N}$ that has occurred in that growing season based on in-season weather up to the time of fertilization. Additionally, the Maize-N model currently does not account directly for $\mathrm{N}$ losses through leaching, denitrification, or volatilization, however these $\mathrm{N}$ losses can be accounted for indirectly by adjusting $\mathrm{N}$ uptake efficiencies from various sources.

The model approach more closely estimated the linearplateau derived ONR than the sensor approach when data is combined across all sites. Additionally, the model-approach recommended $\mathrm{N}$ rates that tended toward over-application of $\mathrm{N}$, resulting in fewer sites where yield was negatively impacted. For this reason, the model approach may be preferable to producers as yield is better protected. Again, newer versions of sensor algorithms maintaining a base $\mathrm{N}$ fertilizer recommendation regardless of the sensor reading potentially negate this concern with canopy sensing. However, with either method there are negative environmental implications of over-application that cannot be ignored.

It is important to consider the restrictions of both approaches. While both approaches are improvements over currently used recommendation systems, they are similarly limited in that they cannot fully predict the effects of weather on crop health and $\mathrm{N}$ availability from the time of in-season $\mathrm{N}$ application until harvest. For the crop canopy sensor approach, at the time of sensing, $\mathrm{N}$ may appear to be adequate in plants; however, this does not indicate if $\mathrm{N}$ supply will be sufficient through the remainder of the growing season. Changes such as $\mathrm{N}$ loss through leaching, volatilization, or denitrification or additions of $\mathrm{N}$ through mineralization that may occur in the remainder of the growing season are not accounted for, as they are not yet expressed in the crop.

User convenience of these approaches is also important to consider. It should be noted that Maize $\mathrm{N}$ requires more up-front information, such as soil residual $N$ supplied by the operator. Another significant difference between the two approaches is the ease of making spatially variable recommendations. The sensor approach rapidly incorporates spatial variability into its recommendation, while making spatially variable recommendations with the model is cumbersome and involves manually inputting different variables such as SOC, residual $\mathrm{N}$, and soil texture. Both approaches are constrained by the user applying in-season $\mathrm{N}$ in a narrow window of time, a condition that may limit adoption where rainfall in the early growing season might prevent in-season $\mathrm{N}$ applications from occurring.

Both the model and sensor approaches have merit; a combination of the two may provide the strongest, most informed $\mathrm{N}$ recommendation. For example, the crop canopy sensor can be used to provide real-time assessment of the crop status while a simulation model can assess expected additions and losses of $\mathrm{N}$ that are not yet reflected by the plant. The sensor approach may be able to identify real-time opportunities such as $\mathrm{N}$ losses reflected in the plant which the Maize- $\mathrm{N}$ model currently does not directly account for. Additionally, crop simulation models can be used to provide estimates of attainable yield, which is valuable for the sensor approach as most current sensor $\mathrm{N}$ recommendation algorithms require either an estimate of expected yield or of ONR. A model approach can also be used to fine-tune sensor-based recommendations according to variation in capacity of soils within a field to mineralize and supply $\mathrm{N}$ to the crop following the time of sensor-based $\mathrm{N}$ application. Combining model and sensor information may optimize in-season decision support for $\mathrm{N}$ recommendation. 


\section{REFERENCES}

Cassman, K.G., A.R. Dobermann, and D.T. Walters. 2002. Agroecosystems, nitrogen-use efficiency, and nitrogen management. Ambio 31:132-140.

Cerrato, M.E., and A.M. Blackmer. 1990. Comparison of models for describing corn yield response to nitrogen fertilizer. Agron. J. 82:138-143. doi:10.2134/agronj1990.00021962008200010030x

Dobermann, A., C.S. Wortmann, R.B. Ferguson, G.W. Hergert, C.A. Shapiro, D.D. Tarkalson, and D.T. Walters. 2011. Nitrogen response and economics for irrigated corn in Nebraska. Agron. J. 103:67-75.

Ferguson, R.B., G.W. Hergert, J.S. Schepers, C.A. Gotway, J.E. Cahoon, and T.A. Peterson. 2002. Site-specific nitrogen management of irrigated Maize. Soil Sci. Soc. Am. J. 66:544-553. doi:10.2136/ sssaj2002.5440

Gitelson, A., and M. Merzlyak. 1995. Signature analysis of leaf reflectance spectra: Algorithm development for remote sensing of chlorophyll.J. Plant Physiol. 148:495-500.

Gitelson, A., M. Merzlyak, and H. Lichtenthaler. 1996. Detection of red edge position and chlorophyll content by reflectance measurements near $700 \mathrm{~nm}$. J. Plant Physiol. 148:501-508. doi:10.1016/ S0176-1617(96)80285-9

Hatfield, J.L., A.A. Gitelson, J.S. Schepers, and C.L. Walthall. 2008. Application of spectral remote sensing for agronomic decisions. Agron. J. 100:S-117-S-131. doi:10.2134/agronj2006.0370c

Holland, K.H., and J.S. Schepers. 2010. Derivation of a variable rate nitrogen application model for in-season fertilization of corn. Agron. J. 102:1415-1424. doi:10.2134/agronj2010.0015

Janssen, B.H., F.C.T. Guiking, D. van der Eijk, E.M.A. Smaling, J. Wolf, and $H$. van Reuler. 1990. A system for quantitative evaluation of the fertility of tropical soils (QUEFTS). Geoderma 46:299-318. doi:10.1016/0016-7061(90)90021-Z

Jones, J.W., G. Hoogenboom, C.H. Porter, K.J. Boote, W.D. Batchelor, L.A. Hunt et al. 2003. The DSSAT cropping system model. Eur. J. Agron. 18:235-265. doi:10.1016/S1161-0301(02)00107-7

Keating, B.A., P.S. Carberry, G.L. Hammer, M.E. Probert, M.J. Robertson, D. Holzworth et al. 2003. An overview of APSIM, a model designed for farming systems simulation. Eur. J. Agron. 18:267-288. doi:10.1016/S1161-0301(02)00108-9

Kersebaum, K.C. 1995. Application of a simple management model to simulate water and nitrogen dynamics. Ecol. Modell. 81:145-156. doi:10.1016/0304-3800(94)00167-G

Mamo, M., G.L. Malzer, D.J. Mulla, D.R. Huggins, and J. Strock. 2003. Spatial and temporal variation in economically optimum nitrogen rate for corn. Agron. J. 95:958-964. doi:10.2134/agronj2003.0958

Melkonian, J.J., H.M. van Es, A.T. DeGaetano, and L. Joseph. 2008. ADAPT-N: Adaptive nitrogen management for maize using highresolution climate data and model simulations. In: R. Kosla, editor, Proceedings of the 9th International Conference on Precision Agriculture, Denver, CO. 20-23 July 2008. (CD-ROM).

Melkonian, J., H.M. van Es, A.T. DeGaetano, J.M. Sogbedji, and L. Joseph. 2007. Application of dynamic simulation modeling for nitrogen management in maize. In: T. Bruulsema, editor, Managing crop nutrition for weather. Int. Plant Nutrition Inst., Peachtree Corners, GA. p. 14-22.

Melkonian, J., H.M. van Es, and L. Joseph. 2005. Precision nitrogen management model: Simulation of nitrogen and water fluxes in the soil-crop-atmosphere continuum in maize (Zea mays L.) production systems. Version 1.0. Res. Ser. no. R05-2. Dep. of Crop and Soil Sciences, Cornell Univ., Ithaca, NY.

Miao, Y.,D.J.Mulla, G.Randall,J.Vetsch, and R.Vintila.2009.Combining chlorophyll meter readings and high spatial resolution remote sensing images for in-season site-specific nitrogen management of corn. Precis. Agric. 10:45-62. doi:10.1007/s11119-008-9091-z
Myrold, D.D., and P.J. Bottomley. 2008. Nitrogen mineralization and immobilization. In: J.S. Schepers and W.R. Raun, editors, Nitrogen in agriculture systems. ASA, CSSA, and SSSA, Madison, WI. p. 157-172.

Raun, W.R., J.B. Solie, G.V. Johnson, M.L. Stone, R.W. Mullen, K.W. Freeman et al. 2002. Improving nitrogen use efficiency in cereal grain production with optical sensing and variable rate application. Agron. J. 94:815-820. doi:10.2134/agronj2002.8150

Roberts, D.F., N.R. Kitchen, P.C. Scharf, and K.A. Sudduth. 2010. Will variable-rate nitrogen fertilization using corn canopy reflectance sensing deliver environmental benefits? Agron. J. 102:85-95. doi:10.2134/agronj2009.0115

SAS Institute. 2008. SAS/STAT user's guide. Version 9.2. SAS Inst., Cary, NC.

Scharf, P.C., N.R. Kitchen, K.A. Sudduth, and J.G. Davis. 2006. Spatially variable corn yield is a weak predictor of optimal nitrogen rate. Soil Sci. Soc. Am. J. 70:2154-2160. doi:10.2136/sssaj2005.0244

Scharf, P.C., and J. Lory. 2006. Integrated pest management best management practices for nitrogen fertilizer in Missouri. Missouri Univ. Ext., Univ. of Missouri-Columbia.

Scharf, P.C., and J.A. Lory. 2009. Calibrating reflectance measurements to predict optimal sidedress nitrogen rate for corn. Agron. J. 101:615625. doi:10.2134/agronj2008.0111

Schmidt, J.P., A.J. DeJoia, R.B. Ferguson, R.K. Taylor, R.K. Young, and J.L. Havlin. 2002. Corn yield response to nitrogen at multiple in-field locations. Agron. J. 94:798-806. doi:10.2134/agronj2002.7980

Setiyono, T.D., H. Yang, D.T. Walters, A. Dobermann, R.B. Ferguson, D.F. Roberts et al. 2011. Maize-N:A decision tool for nitrogen management in maize. Agron. J. 103:1276-1283. doi:10.2134/ agronj2011.0053

Shanahan, J.F., N.R. Kitchen, W.R. Raun, and J.S. Schepers. 2008. Responsive in-season nitrogen management for cereals. Comput. Electron. Agric. 61:51-62. doi:10.1016/j.compag.2007.06.006

Shanahan, J.F., J.S. Schepers, D.D. Francis, G.E. Varvel, W.W. Wilhelm, J.M. Tringe et al.. 2001. Use of remote sensing imagery to estimate corn grain yield. Agron. J. 93:583-589. doi:10.2134/ agronj2001.933583x

Shapiro, C.A., R.B. Ferguson, G.W. Hergert, A.R. Dobermann, and C.S. Wortmann. 2003. Fertilizer suggestions for corn. NebGuide G174. Univ. of Nebraska, Lincoln.

Sheridan, A.H., N.R. Kitchen, K.A. Sudduth, and S.T. Drummond. 2012. Corn hybrid growth stage influence on crop reflectance sensing. Agron. J. 104:158-164. doi:10.2134/agronj2011.0213

Sinclair, T.R., and R.C. Muchow. 1995. Effect of nitrogen supply on maize yield: I. Modeling physiological responses. Agron. J. 87:632-641. doi:10.2134/agronj1995.00021962008700040005x

Smaling, E.M.A., and B.H. Janssen. 1993. Calibration of QUEFTS, a model predicting nutrient uptake and yield from chemical soil fertility indices. Geoderma 59:21-44. doi:10.1016/0016-7061(93)90060-X

Solari, F., J. Shanahan, R. Ferguson, J. Schepers, and A. Gitelson. 2008. Active sensor reflectance measurements of corn nitrogen status and yield potential. Agron. J. 100:571-579. doi:10.2134/ agronj2007.0244

Stöckle, C.O., M. Donatelli, and R. Nelson. 2003. CropSyst, a cropping systems simulation model. Eur. J. Agron. 18:289-307. doi:10.1016/ S1161-0301(02)00109-0

Supit, I., and E. Van der Goot. 2003. Updated system description of the WOFOST crop growth simulation model as implemented in the crop growth monitoring system CGMS, applied by the European Commission. Treemail Publ., Heelsum, the Netherlands.

Yang, H.S., A. Dobermann, K.G. Cassman, and D.T. Walters. 2006. Features, applications, and limitations of the hybrid-maize simulation model. Agron. J. 98:737-748. doi:10.2134/agronj2005.0162

Yang, H.S., and B.H. Janssen. 2000. A mono-component model of carbon mineralization with a dynamic rate constant. Eur. J. Soil Sci. 51:517529. doi:10.1046/j.1365-2389.2000.00319.x 